\title{
ADAPTASI MASYARAKAT PENDATANG (ETNIK MADURA SAMBAS) DENGAN PENDUDUK ASLI
}

\author{
Agus Sikwan \\ Fakultas Ilmu Sosial dan Politik, Universitas Tanjungpura, Jl. Prof. Dr. H. Hadari Nawawi, Indonesia \\ e-mail korespondensi: agus.sikwan@fisip.untan.ac.id
}

\begin{abstract}
Abstrak : Tujuan penelitian ini adalah mengetahui Adaptasi Masyarakat Pendatang (Etnik Madura Sambas) Dengan Penduduk Asli : Studi Di Desa Madu Sari Kecamatan Sungai Raya Kabupaten Kubu Raya. Adapun yang melatarbelakangi penelitian ini adalah banyaknya etnik Madura pasca kerusuhan etnik di Sambas yang mengungsi dan menetap di Desa Madu Sari Kecamtan Sungai Raya Kabupaten Kubu Raya. Dalam proses adaptasi etnik Madura Sambas (pendatang) dengan penduduk asli (masyarakat setempat) banyak mengalami berbagai masalah, khususnya masalah interaksi baik yang menyangkut agama, sosial budaya, ekonomi, dan lain sebagainya. Tujuan dilakukannya penelitian ini adalah untuk mendiskripsikan bagaimana proses adaptasi etnik Madura Sambas (pendatang) dengan penduduk asli setempat di Desa Madu Sari. Adapun metode yang digunakan dalam penelitian ini adalah metode diskriptif dengan pendekatan kualitatif. Sehubungan dengan hal itu, hasil dari penelitian menunjukan bahwa terdapat adaptasi yang baik antara etnik Madura pendatang dengan penduduk setempat, yakni etnik Madura pendatang selalu menjaga silaturahmi dengan penduduk desa setempat, berlaku sopan, ramah tamah, dan ikut bergotong royong pada harihari besar yang ada di desa.
\end{abstract}

Kata kunci: Adaptasi, interaksi, dan etnik Madura Sambas (pendatang).

\begin{abstract}
The purpose of this study was to determine students' perceptions of the implementation of the curriculum, be it about the curriculum, implementation, and evaluation curriculum learning process. The method used is the quantitative method and the form of research is the survey. The results of this study indicate that (1) the perception of students towards higher education curriculum that is organized by the Master Program in Sociology of Education FKIP UNTAN for $21.78 \%$ of the total score of 25, showed that the average student agrees to the curriculum of higher education conducted, (2) students 'perceptions of the organization of higher education curriculum that is organized by the Master Program in Sociology of Education FKIP UNTAN for $21.44 \%$ of the total score of 25 , showed that the average student agrees to the curriculum of higher education conducted, (3) students' perceptions evaluation of higher education learning process organized by the Master Program Sociology Education FKIP UNTAN for $88.4 \%$ of the total score of 86 , showed that the average student agrees to the evaluation of higher education learning process is implemented.
\end{abstract}

Keywords: Adaptation, interaction, and ethnicity of Madura Sambas (migrants).

\section{PENDAHULUAN}

Desa Madu Sari merupakan salah satu Desa yang berada di wilayah Kecamatan Sungai Raya Kabupaten Kubu Raya. Di Desa Madu Sari terdapat orang madura yang mengungsi akibat dari konflik antar suku di Sambas, salah satunya mereka berasal dari
Desa Segarau Sungai, Desa Suka Ramai, Desa Saing Rambi, Desa Tanah Hitam, Desa Sendoyan, dan Desa Sekura. orang Madura (pendatang) mulai pindah ke Desa Madu Sari pada tahun 1999 berjumlah 180 KK dan mulai beradaptasi dengan masyarakat sekitar hingga saat ini hidup rukun dan tentram. 
Pada saat ini kehidupan masyarakat orang Madura (pendatang) di Desa Madu Sari sudah mulai berubah. Salah satunya dari segi pendidikan, segi ekonomi dan interaksi sosial dengan sesama orang Madura dan orang lainnya. Hal ini dibuktikan dengan adanya sebagian anak-anak dari mereka yang sadar akan arti pentingnya pendidikan, sehingga banyak dari mereka yang melanjutkan sekolah kejenjang perguruan tinggi. Selain itu dari segi ekonomi, mereka orang Madura (pendatang) yang dulunya hanya bekerja sebagai buruh tani, petani karet, dan peternak kini diantara mereka sudah memiliki pekerjaan yang lebih baik lagi. Misalnya saja mereka mendirikan usaha seperti toko kelontong, bengkel motor, rumah makan, dan warung internet. Interaksi sosial yang terjadi diantara sesama suku dan antar suku lain yang berada di Desa Madu Sari juga berjalan dengan rukun dan damai. Hal ini dilihat dari kekompakan yang mereka miliki seperti bergotong-royong, melakukan pengajian diantara ibu-ibu, dan jika ada acara, merekapun ringan tangan untuk membantu terlaksananya acara tersebut.

Adaptasi adalah suatu penyesuaian pribadi terhadap lingkungan, penyesuaian ini dapat berarti mengubah diri pribadi sesuai dengan keadaan lingkungan, juga dapat berarti mengubah lingkungan sesuai dengan keinginan pribadi. Menurut Karta Sapoetra (2008:36) adaptasi mempunyai dua arti. Adaptasi yang pertama disebut penyesuaia ndiri yang autoplastis (auto artinya sendiri, plastis artinya bentuk), sedangkan pengertian yang kedua penyesuaian diri yang alloplastis (allo artinya yang lain, plastis artinya bentuk). Jadi adaptasi ada yang artinya "pasif" yang mana kegiatan pribadi ditentukan oleh lingkungan. Dan ada yang artinya "aktif" yang mana pribadi mempengaruhi lingkungan.

Menurut Suparlan (2014:57) adaptasi itu sendiri pada hakekatnya adalah suatu proses untuk memenuhi syarat-syarat dasar untuk tetap melangsungkan kehidupan. Syarat-syarat dasar tersebut sebagai berikut, Syarat dasar alamiah-biologi (manusia harus makan dan minum untuk menjaga kesetabilan tempratur tubuhnya agar tetap berfungsi dalam hubungan harmonis secara menyeluruh dengan tubuh lainnya). Syarat dasar kejiwaan (manusia membutuhkan perasaan tenang yang jauh dari perasaan takut, keterpencilan gelisah). Syarat dasar sosial (manusia membutuhkan hubungan untuk dapat melangsungkan keturun, tidak merasa dikucilkan, dapat belajar mengenai kebudayaannya, untuk dapat mempertahankan diridari serangan musuh).

Menurut Soerjono Soekanto (2009:98) memberikan beberapa batasan pengertian dari adaptasi, yakni, Proses mengatasi halanganhalangan darilingkungan, Penyesuaian terhadap norma-norma untuk menyalurkan, Proses perubahan untuk menyesuaikan dengan situasi yang berubah, Mengubah agar sesuai dengan kondisi yang diciptakan, Memanfaatkan sumber-sumber yang terbatas untuk kepentingan lingkungan dan sistem. Dan penyesuaian budaya dan aspek lainnya sebagai hasil seleksi alamiah. Dari batasan-batasan tersebut dapat disimpulkan bahwa adaptasi merupakan proses penyesuaian. Penyesuaian dari individu, kelompok, maupun unit social terhadap norma-norma, proses perubahan ataupun suatu kondisi yang diciptakan. Lebih lanjut tentang proses penyesuaian tersebut. Aminuddin (2000:54) menyebutkan bahwa penyesuaian dengan tujuan-tujuan tertentu, diantaranya: mengatasi halangan-halangan dari lingkungan, menyalurkan ketegangan sosial, mepertahankan kelanggengan kelompok atau unit sosial dan bertahan hidup.

Di dalam adaptasi juga terdapat pola-pola dalam menyesuaikan diri dengan lingkungan. Menurut Suyono (2009:24), pola adalah suatu rangkaian unsur-unsur yang sudah menetap mengenai suatu gejala dan dapat di pakai sebagai contoh dalam hal menggambarkan atau mendeskripsikan gejala itu sendiri. Dari definisi tersebut diatas, pola adaptasi dalam penelitian ini adalah sebagai unsur-unsur yang sudah menetap dalam proses adaptasi yang dapat menggambarkan proses adaptasi dalam kehidupan sehari-hari, baik dalam interaksi, tingkah laku maupun dari masing-masing adatistiadat kebudayaan yang ada. Proses adaptasi berlangsung dalam suatu perjalanan waktu yang tidak dapat diperhitungkan dengan tepat, kurun waktunya bisa cepat, lambat, atau justru berakhir dengan kegagalan.

Etnis atau suku merupakan suatu kesatuan sosial yang dapat dibedakan dari kesatuan yang lain berdasarkan akar dan identitas kebudayaan, terutama bahasa. Dengan kata lain etnis adalah kelompok manusia yang terikat oleh kesadaran dan identitas tadi sering 
Volume 12 | Number 1| April |2021, Page 13-23/ E-ISSN: 2715-1247 dan P-ISSN: 2087-84xx

kali dikuatkan oleh kesatuan bahasa (Koentjaraningrat, 2007:90). Dari pendapat diatas dapat dilihat bahwa etnis ditentukan oleh adanya kesadaran kelompok, pengakuan akan kesatuan kebudayaan dan juga persamaan asal-usul.

Wilbinson (Koentjaraningrat, 2007:90) mengatakan bahwa pengertian etnis mungkin mencakup dari warna kulit sampai asal-usul sacuan kepercayaan, status kelompok minoritas, kelas stratafikasi, keanggotaan politik bahkan program belajar.

Selanjutnya Koentjaraningrat (2007:90) juga menjelaskan bahwa etnis dapat ditentukan berdasarkan persamaan asal-usul yang merupakan salah satu faktor yang dapat menimbulkan suatu ikatan. Berdasarkan teoriteori di atas dapat disimpulkan bahwa etnis atau suku merupakan suatu kesatuan sosial yang dapat membedakan kesatuan berdasarkan persamaan asal-usul seseorang sehingga dapat dikategorikan dalam status kelompok mana yang dimasukkan. Istilah etnis ini digunakan untuk mengacu pada satu kelompok, atau ketegorisosial yang perbedaannya terletak pada kriteria kebudayaan.

Secara sederhana, teori fungsionalisme struktural adalah sebuah teori yang pemahamannya tentang masyarakat didasarkan pada model sistem organik dalam ilmu biologi. Artinya, fungsionalisme melihat masyarakat sebagai sebuah sistem dari beberapa bagian yang saling berhubungan satu dengan lainnya. Satu bagian tidak bisa dipahami terpisah dari keseluruhan

Hubungan terjadi ketika manusia memasuki pola interaksi yang relatif stabil dan berkesinambungan dan/atau saling ketergantungan yang menguntungkan. Maka pola struktur sosial dapat dipengaruhi oleh jumlah orang yang berbeda-beda, kedudukan seseorang dan peran yang dimiliki individu dalam jaringan hubungan sosial. Perlu dipahami bahwa struktur sosial merupakan lingkungan sosial bersama yang tidak dapat diubah oleh orang perorang. Sebab ukuran, pembagian kegiatan, penggunaan bahasa, dan pembagian kesejahteraan didalam organisasi merupakan pembentuk lingkungan sosial yang bersifat struktural dan membatasi perilaku individu dalam organisasi.
Teori fungsionalisme struktural Talcott Parsons (2009:34), mengungkapkan suatu keyakinan yang optimis terhadap perubahan dan kelangsungan suatu sistem. Talcott Parsons berpendapat bahwa ada empat subsistem yang menjalankan fungsi-fungsi utama dalam kehidupan bermasyarakat yaitu adaptation, goal attainment, intergration, dan lattent pattern mainteance. Keempat skema penting tersebut tidak memiliki batasan yang jelas, Karena satu sama lain saling berkesinambungan. Mengenai fungsi untuk semua system tindakan, skema tersebut dikenal dengan skema AGIL, teori fungsionalisme struktural dalam menganalisis tindakan sosial. Keempat fase tersebut digambarkan dalam menganalisis tindakan sosial orang Madura (pendatang) berupa: Adaptation (Adaptasi) Ialah sebuah sistem yang berfungsi menanggulangi situasi eksternal yang gawat. Sistem ini dimaksudkan setiap individu harus menyesuaikan diri dengan lingkungan dan menyesuaikan lingkungan itu dengan kebutuhannya. Berbagai dimensi permasalahan harus ada penyesuaian diri sistem ituterhadap tuntutan kenyataan yang keras, yang tidak dapat diubah (inflexible) yang datang dari lingkungan. Sama halnya dengan orang Madura (pendatang) yang mempunyai keharusan dalam menyesuaikan diri dengan lingkungan eksternalnya. Dalam hal ini lingkungan eksternal tersebut berupa masyarakat yang memilik adat, kebiasaan dan norma yang tidak dapat diubah begitu saja. Goal Attainment (PencapaianTujuan) Ialah sebuah sistem yang berfungsi harus mendefinisikan dan mencapai tujuan utamanya. Dalam halini orang Madura (pendatang) harus tetap berpegang pada tujuan utama adaptasinya yaitu mengubah stigma negatif yang melekat pada dirinya setelah pindah ke Desa Madu Sari.

Integration (Integrasi) ialah sebuah system harus mengatur antar hubungan bagian-bagian yang menjadi komponennya. Sistem juga harus mengelola antarhubungan ketiga fungsi penting lainnya $(A, G, I, L)$. hal tersebut penting dilakukan agar suatu system social berfungsi secara efektif sebagai suatu kesatuan, harusada paling kurang suatu tingkat solidaritas diantara individu yang termasuk di dalamnya. Masalah integrasi merujuk pada kebutuhan untuk menjamin bahwa ikatan 
emosional yang cukup menghasilkan solidaritas dan kerelaan untuk bekerjasama dikembangkan dan dipertahankan. Orang Madura (pendatang) harus memiliki ikatan emosional kepada masyarakat di dalam lingkungannya. Upaya tersebut agar terjalin integrasi antar sesama warga yang nantinya akan memunculkan solidaritas dan dapat diterimanya orang Madura (pendatang) oleh masyarakat.

Latency (Latensi atau Pemeliharaan Pola) ialah sebuah system harus melengkapi, memelihara, dan memperbaiki, baikmotivasi individual maupun pola-pola kultural yang menciptakan dan menopang motivasi. Pada tahapan ini akan terciptanya suatu pola yang tetap menjadi cirikhas seperti halnya kekhasan suatu masyarakat disuatu wilayah. Orang Madura (pendatang) yang telah memahami pola dalam suatu masyarakat akan memudahkannya untuk beradaptasi dan berusaha mengikuti dan memelihara norma yang terdapat di dalam lingkungan masyarakat tempat dia berada.

Berdasarkan teori Talcott Parsons di atas, maka dapat dilihat jika orang Madura (pendatang) yang mampu beradaptasi secara baik akan terus memelihara pola yang akan mempengaruhinya dalam mengambil suatu tindakan sosial. Keharusan orang Madura (pendatang) dalam beradaptasi dengan mempunyai tujuan untuk mengubah stigma yang dilakukan dengan menunjukan integritasnya sebagai warga masyarakat. Tentunya kebersamaan untuk mengikuti atau memelihara norma yang terdapat di lingkungan setempat akan membuat proses adaptasi dan penerimaan akan dirinya berjalan dengan cepat.

\section{METODE}

Jenis penelitian yang digunakan dalam penelitian ini adalah jenis penelitian deskriptif dengan pendekatan kualitatif. Adapun yang dimaksud dengan penelitian deskriptif yaitu penelitian yang menggambarkan fenoman fenomena yang terjadi dilapangan sesuai keadaan yang sebenarnya, dengan prosedur pemecahan masalah berdasarkan keadaan sebagaiman adanya (apadanya). Sedangkan menurut Nawawi (2005:31), bahwa penelitian deskriptif dapat diartikan sebagai prosedur pemecahan masalah diselidiki dengan menggambarkan atau melukiskan keadaan subjek atau objek penelitian (seseorang, lembaga, masyarakat, dan lain-lain) pada saat sekarang berdasarkan fakta yang tampak sebagaimana adanya.

Penentuan subjek penelitian dalam metode ini menggunakan metode purposive, yang berarti tempat penelitian dan subjek yang akan diteliti benar-benar telah informan tersebut pahami dan ketahui. Informan tersebut juga telah memahami dengan baik dan dan lengkap terhadap informasi yang ingin diketahui berdasarkan fakta permasalahan yang ada, serta informan dimungkinkan menjadi pelaku maupun pemberi alasan dalam permasalahan penelitian ini.

Penelitian ini menggunakan informan yang terdiri dari pertama informan pangkal, dan kedua informan pokok, Informaninforman tersebut yakni sebagai berikut, Informan Kunci: Kepala Desa Madu Sari, Ketua RT dan Ketua RW. Informan adalah masyarakat etnik Madura Sambas dan telah pindah ke Desa Madu Sari Kecamatan Sungai Raya Kabupaten Kubu Raya yang diambil secara purposive sampling dengan kriteria sebagai berikut, Orang Madura (pendatang) dari Sambas yang sudah menetap kurang lebih 3 tahun di Desa Madu Sari Kecamatan Sungai Raya Kabupaten Kubu Raya, memiliki usia yang tergolong usia dewasa atau usia produktif, merupakan korban dari kejadian/kerusuhan etnik di Sambas

\section{HASIL DAN PEMBAHASAN}

\section{Proses Adaptasi Orang Madura Sambas di Desa Madu Sari}

Sebelum terjadinya konflik antar etnis di Sambas, Kehidupan orang Madura disana terbilang cukup baik dan aman. Hal ini dibuktikan dengan mata pencaharian mereka yang mencukupi seperti mereka memiliki kebun lada, peternakan sapi, persawahan dan tanah yang berhektar-hektar, namun setelah terjadinya konflik Sambas, kehidupan orang Madura berubah menjadi tidak kondusif sehingga membuat mereka terpaksa pindah dari tempat asal mereka ke Desa Madu Sari.

Orang Madura Sambas pindah ke Desa Madu Sari dengan meninggalkan semua harta benda mereka, dikarenakan mereka harus memilih keselamatan mereka dibandingkan harta benda yang mereka miliki. Setelah orang Madura Sambas memutuskan untuk pindah 
dari daerah asal mereka ke Desa Madu Sari, mereka harus memulai kehidupan mereka dari nol lagi, tentunya itu semua tidak mudah bagi mereka, mereka harus mencari tempat tinggal baru, pekerjaan baru dan penyesuaian dengan lingkungan yang baru.

Adaptasi orang Madura korban konflik etnis Sambas di lingkungan masyarakat Desa Madu Sari meliputi interaksi sosial dan aktivitas sosial. Interaksi sosial orang Madura pasca konflik Sambas di lingkungan masyarakat Desa Madu Sari yaitu dapat berupa sikap sosial dan komunikasi dengan masyarakat sekitar.

\section{Adaptasi Orang Madura Sambas (Pendatang) di Lingkungan Eksternal Masyarakat Desa Madu Sari}

Berdasarkan hasil penelitian diperoleh bahwa terdapat berbagai tindakan yang dilakukan orang Madura (pendatang) dalam beradaptasi dengan lingkungan masyarakat yaitu dengan menunjukkan sikap ramah, ikut berperan aktif dalam kegiatan kemasyarakatan seperti gotong-royong, bakti social sampai membantu masyarakat sekitar jika terkena musibah atau hajatan serta tidak lagi melakukan hal-hal yang dapat dinilai negatif oleh masyarakat.

Berdasarkan hasil penelitian yang dilakukan terkait interaksi sosial orang Madura (pendatang) dengan lingkungan masyarakat setempat, diketahui bahwa interaksi sosial yang dilakukan SN (informan) dengan masyarakat setempat tetap terjalin dengan baik meskipun SN adalah seorang pendatang, pola adaptasi yang dilakukan SN dengan masyarakat yaitu dengan cara ikut berperan aktif dalam kegiatan kemasyarakatan sekitarnya, SN juga mengungkapkan bahwa dirinya tetap berkumpul dengan tetangga sekitar rumahnya, bahkan SN merasa lebih dekat dengan masyarakat sekitar karena sejak datang ke Desa Madu Sari sampai saat ini SN menunjukan perilaku yang baik hingga saat SN bekerja sebagai petani dengan masyarakat sekitar.

Berikut ini pernyataan Hasil Wawancara dengan SN

...engkok pertama pinda e dinnak alhamdulillah langsung e teremah dengan baek bik masyarakat tapeh dengan syarat tak boleh ngebei masalah pole harus a tengkah begus ben masyarakat dinnak. Se pertama nerima engkok $r t$ asmad bae korengah langsung e kena laki kemasyarakat. Deri waktu juahlah engkok langsung nyaman a kompol ben masyarakat.

[Saya pertama pindah kesini tu almadulillah langsung di terima dengan baik oleh masyarakat sekitar, tapi dengan syarat tidak boleh membuat masalah. Harus berbuat baik dengan masyarakat di sini. Orang yang pertama nerima saya disini adalah pak asmad selaku RT disini, orang nyabaik dan langsung di kenalkan kemasyarakat sekitar].

Pernyataan SN diterima oleh lingkungan masyarakat tempat tinggalnya diperkuat oleh pernyataan Ketua RT tempatt inggalnya setelah diwawancara sebagai informan pangkal, ketua RT AD mengatakan bahwa dirinya pribadi tetap menerima dengan baik kehadiran $\mathrm{AD}$ meskipun $\mathrm{SN}$ adalah seorang pendatang, ketua RT AD juga mengungkapkan bahwa SN banyak memperlihatkan perilaku yang baik.

\section{Adaptasi Orang Madura Sambas (Pendatang) di Lingkungan Internal Masyarakat Desa Madu Sari}

Keluarga merupakan tempat yang menjadi tujuan utama bagi orang Madura (pendatang) ketika pindah ketempat tinggal yang baru. Keluarga memiliki peranan yang sangat penting dalam penyesuaian diri orang Madura (pendatang) sehingga dukungan keluarga sangatlah dibutuhkan oleh orang Madura (pendatang) untuk memperbaiki diri dan kembali dalam lingkungan masyarakat. Berdasarkan hasil wawancara di ketahui bahwa keinginan orang Madura (pendatang) untuk dapat beradaptasi membutuhkan dukungan dari keluarga. Dukungan itu dapat berupa bimbingan dan nasehat yang diberikan keluarga untuk orang Madura (pendatang).

Saat penulis menanyakan tanggapan keluarga terhadap informan, SN mengungkapkan bahwa seluruh anggota keluarga istri, anak, dan saudara telah menerima keputusan SN dengan baik, serta maubersama-sama untuk beradaptasi dengan lingkungan yang baruyaitu di Desa Madu Sari. 
Volume 12 | Number 1| April |2021, Page 13-23/ E-ISSN: 2715-1247 dan P-ISSN: 2087-84xx

Berikut ini pernyataan SN:

...pertamanah engkok deteng kedena kbeng tang keloargah, alhamdulillah engkok $e$ beridukungan bi keluarga. Benyak se emberi nasehat keengkok, kapih neremah engkok pendahkedenak. Bik tang keluarga e nyareh akihlakoh, eberi pengertian supajehter biasa beng lingkungan denak.

[pertama saya datang kesini Bersama keluarga, alhamdulillah saya selalu diberikan dukungan oleh keluarga. Banyak yang memberikan nasehat kepada saya, semua menerima saya pindah kesini. Oleh keluarga saya dicarikan kerja, di berikan pengertian supaya terbiasa dengan lingkungan sekitar].

Berdasarkan ungkapan yang disampaikan SN di atas, menunjukkan bahwa SN mendapatkan dukungan dari keluarganya. Keluarga SN akan selalu mendukung, dan memberi nasehat agar SN tidak merasa sendiri dalam memualai adaptasi atau penyesuaian diri di lingkungan keluarga, SN menyadari dan menerima segala nasehat yang di berikan keluarga untuknya. Dengan demikian keluarga merupakan tempat untuk berbagi cerita, cinta kasih dan kaih sayang.

\section{Hambatan Yang Dialami Orang Madura (Pendatang) Dalam Beradaptasi Di Lingkungan Masyarakat Desa Madu Sari}

Setiap individu yang pernah mengalami trans migrasi kesuatu wilayah yang baru tentunya membutuhkan penyesuaian terhadap lingkungan yang baru. Maka dari itu dengan adanya upaya dari setiap orang Madura (pendatang) untuk memperbaiki kesalahan dahulu sehingga bias diterima masyarakat. Seiring dengan upaya adaptasi orang Madura (pendatang) agar dapat diterima dalam lingkungan masyarakat tidak terlepas dari hambatan-hambatan yang dapat menyebabkan lambatnya proses adaptasi yang dilakukan orang Madura (pendatang) dengan lingkungan sekitarnya. Peran dari lingkungan dan masyarakat itusendiri yang harus menentukan bagaimana menerima setiap pendatang kelingkungan tempat tinggalnya.

Berdasarkan hasilpenelitian dilapangan diperoleh bahwa hambatan utama yang dialami oleh orang Madura (pendatang) di Desa Madu Sari yaitu: kurangnya kepercayaan diriorang Madura (pendatang) untuk beradaptasi dengan lingkungan sekitarnya. Hal tersebut karena adanya status tambahan bagiorang Madura (pendatang) dan merupakan adanya interaksionisme simbolik yang muncul ketika status pendatang yang melekat pada dirinya. Namun keinginan yang besar orang Madura untuk diterima dalam lingkungan dan masyarakat menjadi sebuah kekuatan bagi mereka untuk tetap beradaptasi dengan mejadikan semua kritikan dan tekanan dari masyarakat dan lingkungan sekita rmeja disebuah motivasi dan nasehat bagi dirinya halini sesuai dengan hasil wawancara salah satu orang madura (pendatang) yang bernama NH mengatakanbahwa:

...pertama deteng e denna kengkoktodus rasanah, karna engkok kanpendatang jadi ketemuan ben oreng johtodus. Sebenarnya masyarakat jehneremahcoman engkok engseht aknyaman. Tako keng masyarakat edennak mekereng kokjeh bakalan menyala teros ngebeionar pola nah engkok jeh pendatang. Tapeh setiah engko kenjek takto duskiyah ke masyarakat pola nah engkok jeha baur kemasyarakat, akompol kepengajian setiapmalem jum'at. Teros engkok eberibimbingan nasehat bapak ustadz beng pak Rt serta bik masyarakat setempat.

[Pertama dating kesini saya merasa malu, karena saya orang pendatang jadi malu untuk ketemu sama orang. Sebenarnya masyarakat disini menerima kehadiran saya sebagai orang pendatang, Cuma saya merasa kalau orang disini mengira kalau saya akan membuat masalah, tapi saya tidak perduli dengan omongan orang, saya setiap malam jumat selalu berinteraksi dengan masyarakat, ikut pengajian setiap malam jumat dan mendengarkanceramah dan nasehat dari pak ustadz dan tokoh-tokoh masyarakat di DesaMadu Sari].

Cepat atau lambatnya keberhasilan orang Madura (pendatang) dalam berdaptasi dengan lingkungannya selainditentukan oleh factor lingkungan juga sangat ditentukan oleh dirinya sendiri, bagai mana dia menyikapi kondisi sekitar dengan agar tujuan utama dalam beradaptasi dapat tercapai. Hal ini juga sesuai dengan teori fungsionalisme yaitu Struktural fungsionalisme berjalan melalui individuindividu sebagai actor dengan menjalankan 
fungsi dan perannya masing-masing melalui bentuk adaptasi terhadap subsistem structural fungsionalisme, yang menghasilkan sebuah tindakan. Dari tindakan inilah kemudian terjadi sistemaksi (act system) dimana masyarakat telah menemukan tujuan dari aksi tersebut.

Adaptasi orang Madura (pendatang) terhadap lingkungan masyarakat meliputi adaptasi terhadap perubahan-perubahan diri orang Madura (pendatang) dan perubahanperubahan masyarakat sekitar orang Madura (pendatang). Dalam konteks penelitian ini, penulis menggunakan teori fungsionalisme yang dikembangkan oleh Talcott Parsons pada intinya teori fungsionalisme untuk menganalisa pola adaptasi orang Madura pasca konflik Sambas di lingkungan masyarakat Desa Madu Sari Kecamatan Sungai Raya. Teori fungsionalisme structural menekan kepada keteraturan dan perubahan dalam masyarakat.

Dalam hal ini dijelaskan pola Adaptasi yang dilakukan orang Madura (pendatang) dalam upaya mengubah stigma negatif yaitu pendatang, yang meliputi:

1. Menunjukan sikap ramah Penunjukan sikap ramah yang dilakukan oleh orang Madura (pendatang) dengan memberikan teguran atau sapaan ketika bertemu dengan tetangga dan masyarakat sekitar serta bersikap lembut dan menghargai tetangga.

2. Berperan aktif membantu tetangga, Membantu tetangga yang sedang kesulitan, orang Madura (pendatang) selalu memberikan pertolongan kepada tetangga yang sedang mengalami kesulitan. Hal tersebut merupakan perwujudan dari bentuk kepedulian orang Madura (pendatang) kepada tetangga sekitar yang mengalami kesulitan atau musibah.

3. Menjalin komunikasi yang baik dengan tetangga dan lingkungan sekitar Yaitu mengobrol bersama, dan saling berbagi merupakan cara yang dilakukan orang Madura (pendatang) di dalam kehidupan sehari-hari bersama tetangga dan masyarakat sekitar di Desa Madu Sari. Dengan menjalin komunikasi yang baik, orang Madura (pendatang) menjadi merasa dimengerti dengan keadaan yang dialami oleh diriorang Madura (pendatang).
4. Berpartisipasi aktif dalam kegiatan yang ada di dalam masyarakat, orang Madura (pendatang) mencoba berinteraksi dengan bergaul dan membaur di dalam masyarakat. Cara yang dilakukan dalam upaya agar diterima dengan baik adalah dengan berpartisipasi dalam setiap kegiatan kemasyarakatan. Kegiatan yang dilakukan seperti menghadiri setiap acara seperti pernikahan, syukuran, gotong-royong dan lain-lain.

5. Menanggapi stigma negatip dengan bersikap biasa saja, memberikan respon atas pandangan tetangga dan masyarakat sekitar dengan biasa saja, cuek, tetap percaya diri, menyadari kesalahan dan menunjukannya dengan sikap positif dari setiap kegiatan yang sudah dijalani. Setiap manusia terlahir sebagai makhluk sosial yang tidak bisa lepas dari manusia lainnya dan bermasyarakat. Keinginan yang mendorong manusia untuk hidup bermasyarakat adalah hasrat sosial, hasrat untuk mempertahankan diri, hasrat berjuang, hasrat harga diri, hasrat meniru, hasrat bergaul, hasrat untuk mendapatkan kebebasan, hasrat untuk memberitahukan, hasrat tolong-menolong dan simpati (Ahmadi 1975:40). Hal itulah yang sangat mendasari orang Madura (pendatang) untuk hidup damai dan berharap diterima dengan baik di tengah masyarakat Desa Madu Sari. Mereka mencoba untuk melakukan proses adaptasi dengan menjalin interaksi yang baik bersama tetangga dan masyarakat sekitar. Oleh karena itu, sejatinya setiap warga masyarakat menginginkan adanya pengakuan dan penerimaan atas dirinya didalam suatu lingkungan masyarakat.

Adaptasi yang dilakukan orang Madura (pendatang) untuk bias diterima dengan baik dan sekaligus menghilangkan stigma masyarakat terhadap pendatang bukanlah hal yang mudah untuk dilakukan. Menurut Schneider bahwa untuk melakukan adaptasi sosial, dapat dilakukan dengan beberapa syarat yang harus dipenuhi, yaitu:

1. Menyadari dan menghargai hak-hak yang dimiliki orang lain di dalam lingkungan masyarakat;

2. Membangun persahabatan dengan orang lain dan mengembangkan persahabatan yang berlangsung untuk waktu yang lama; 
3. Perlu adanya minat dan simpati untuk kebaikan orang lain; Berbagi dan suka menolong yang merupakans yarat selain minat dan simpati;

4. Menghargai norma dan integritas dari hukum, tradisi, dan kebiasaan yang berlaku dalam masyarakat.

Hak-hak yang dimiliki orang lain tentu menjadi syarat untuk dapat melakukan proses adaptasi. Hak-hak tersebut dapat diwujudkan dengan menghargai setiap pendapat masyarakat dan menunjukan sikap toleransi kepada warga masyarakat di lingkungan tempat tinggal orang Madura (pendatang) berada. Persahabatan dibangun dengan sesame warga sejatinya sangat penting dilakukan agar terjalin ikatansolidartias antar sesamawarga masyarakat. Dengan menjalin hubungan persahabatan seca rabaik, orang Madura (pendatang) diharapkan menjadi pribadi yang mampu diterima oleh lingkungan sosialnya.

Masalah terbesar yang dialami orang Madura (pendatang) setelah pindah ke Desa Madu Sari yaitu kekhawatiran mereka terhadap lingkungan sekitar yang menganggap orang Madura (pendatang) nantinya akan melakukan kesalahan dan membuat masalah lagi ditengah masyarakat. Selain itu, terjadi masalah psiko-sosial pada diri mereka. Masalah tersebut seperti pengucila nsosial, pelabelan dan kerugian. Beberapa orang Madura (pendatang) mengungkapkan bahwa setelah mereka pindah ke Desa Madu Sari, orang Madura (pendatang) mereka menemui hambatan dalam beradaptasi dengan lingkungan sekitar, yang mana mereka membutuhkan proses yang cukup lama untuk bersosialisasi dengan tetangga dan masyarakat di lingkungan Desa Madu Sari.

Berdasarkan temuan yang dilakukan oleh Georgul dan Erden tidak terjadi suatu masalah yang terlalu besar. Sesuai dengan karakter masyarakat Indonesia yang menginginkan hidup damai dan sejahtera, sehingga masyarakat dalam suatu wilayah di Indonesia memiliki ikatan solidaritas dan kekeluargaan yang kuat. Ketika orang Madura (pendatang) dating dari tempat asalnya, masyarakat sangat berperan penting merangkul dan mendekatkan diri dengan orang Madura (pendatang), sehingga terjalin hubungan yang baik. Hal tersebut ditunjukkan dengan saling menasehati dan memotivasi yang pada akhirnya akan memberikan kepercayaan diri kepada orang Madura (pendatang) untuk mencoba bergaul dan beradaptasi ulang di tengah masyarakat.

\section{Bentuk Perubahan yang Terjadi Pada Orang Madura Sambas (Pendatang) di Lingkungan Masyarakat Desa Madu Sari}

Setelah pindah ke Desa Madu Sari, orang Madura (pendatang) memiliki perubahan menuju kearah positif. Perubahan positif yang dilakukan orang Madura (pendatang) setelah pindah ke Desa Madu Sari antara lain:

1. Bertambah ikatan kedekatan dengan tetangga dan masyarakat sekitar. Banyak mendapat pelajaran hidup selama pindahke Desa Madu Sari melaui bimbingan daritokoh agama dan tokoh masyarakat setempat yang membuat adasuatu perbedaan dalam hal spiritual yang terdapat dalam diriorang Madura (pendatang). Selain menyadari akan dosa yang diperbuatnya di masa lalu, setelah pindah ke Desa Madu Sari orang Madura (pendatang) terlihat lebih terbuka dan lebih dekat dengan tetangganya dan masyarakat sekitar karena kesadaran akan pentingnya hidup rukun dan damai dalam kehidupan bermasyarakat.

2. Lebih peka dan aktif dalam kegiatan kemasyarakatan. Sikap yang cuek merupakan sikap yang dulunya dimiliki oleh orang Madura (pendatang). Namun, setelahorang Madura (pendatang) pindah ke Desa Madu Sari, orang Madura (pendatang) menunjukan perubahan dalam dirinya dengan aktif dalam kegiatan kemasyarakatan, seperti selalu menghadiri acara pernikahan, syukuran, dan gotongroyong di lingkungan sekitar. Perubahan tersebut diharapkan mampu memperlihatkan sisipositif orang Madura (pendatang) yang ingin berubah dan bergaul dengan masyarakat sehingga diterima dan diakui keberadaannya sebagai bagian dari warga setempat.

3. Menjauhi pergaulan dan kebiasaan di masa lalu. Lingkungan merupakan agen sosialisasi yang sangat eratkaitannya dalam pembentukan kepribadian seseorang. Seharusnya yang dilakukan orang Madura (pendatang) ialah membuang masa lalu dan mencoba beradaptasi ulang dengan rekan masyarakat tempat tinggal yang memiliki energy untuk menjadi kan orang Madura (pendatang) berprilaku positif pula. 
Berbagai bentuk perubahan positif orang Madura (pendatang) terhadap lingkungan tetangga dan masyarakat tersebut dapat dikatakan sebagai buah hasil dari bimbingan para tokoh agama dan tokoh masyarakat setempat. Perubahan didukung oleh proses bimbingan daritokoh agama juga didukung oleh dukungan dari berbagai pihak seperti tetangga dan masyarakat tempat tinggal orang Madura (pendatang). Hal ini diharapkan melalui bimbingan dari berbagai pihak, orang Madura (pendatang) tentunya nanti mereka akan menyadari kesalahan, memperbaiki diri, menjadi manusia yang lebih baik lagi dan tidak mengulangi hal-hal yang dapat merugikan diri sendiri, orang lain maupun berbagai pihak sehingga dapat diterima kembali oleh lingkungan masyarakat, dapat aktif berperan dalam pembangunan, dan dapat hidup secara wajar sebagai warga yang baik dan bertanggung jawab. Oleh karena itu, diharapkan dengan diterimanya orang Madura (pendatang) dengan baik ini merupakan upaya agar orang Madura (pendatang) mampu berubah dan memperbaiki diri dengan bimbingan dari tokoh agama dan tokoh masyarakat setempat. Upaya-upaya tersebut dapat berupa berbagai kegiatan pengajian, salat berjamaah, siraman rohani dan kegiatan keagamaan lainnya di dalam lingkungan masyarakat Desa Madu Sari.

Orang Madura (pendatang) tentunya memiliki kebiasaan yang sering dilakukan semasa masih hidup bebas sebelum pindah ke Desa Madu Sari. Berdasarkan data yang dihimpun dari informan, orang Madura (pendatang) memiliki kebiasaan buruk seperti berperilaku keras, ego yang tinggi, keras kepala dan maumenang sendiri hingga tindak kejahatan lainnya. Dengan adanya bimbingan tersebut diharapkan terciptanya suatu energy baru dalam diri orang Madura (pendatang) agar menyadari kebiasaan buruk tersebut. Interaksi dan reintegrasi adalah upaya yang dilakukan untuk memperbesar kemauan masyarakat untuk menerima orang Madura (pendatang) dengan baik dan meminimalkan stigma negatif, sehingga ketika berinteraksi, orang Madura (pendatang) diharapkan dapat hidup kembali secara normal sebagai anggota masyarakat.

\section{Dampak Adaptasi Orang Madura Sambas (Pendatang) di Lingkungan Masyarakat Desa Madu Sari}

Setiap individu yang telah mengalami suatu tragedi besar tentunya akan merasakan rasa trauma akibat dari kejadian tersebut, maka dengan itu adanya upaya dari setiap mantan orang Madura (pendatang) untuk kembali hadir dan memperbaiki kesalahan dahulu harus diterima kembali oleh masyarakat. Dampak yang terjadi setelah orang Madura (pendatang) melakukan adaptasi di dalam lingkungan masyarakat berdasarkan hasil penelitian di Desa Madu Sari, sebagai berikut:

1. Perubahan respon dari tetangga dan lingkungan masyarakat sekitar. masyarakat yang awalnya merasa khawatir dan kurang percaya ketika melihat orang Madura (pendatang) adalah orang-orang yang merupakan hasil dari kerusuhan Sambas. Oleh karena itu orang Madura (pendatang) setelah pindah ke Desa Madu Sari perlahan berubah seiring proses adaptasi yang dilakukan individu dalam upaya mengubah stigma negative dalam dirinya, hingga saat ini seluruh masyarakat Desa Madu Sari sudah mulai menerima orang Madura (pendatang) dengan baik ketika melihat perubahan dan penerimaan diri oleh masyarakan dalam kehidupan sehari-hari.

2. Hilangnya stigma negatip dari tetangga maupun masyarakat sekitar. Setelah orang Madura (pendatang) melakukan proses adaptasi dengan melakukan interaksi dan menjalin hubungan yang baik dengan tetangga dan lingkungan sekitar baik melalui tegur sapa, sopan santun, serta tolong menolong, terlibatnya orang Madura (pendatang) dalam kegiatan kemasyarakatan dan penunjukan perubahan diri mengakibatkan stigma negatif di dalam masyarakat yang awalnya kuat perlahan mulai hilang. Hal tersebut karena masyarakat juga merupakan agen yang mampu menilai dan mengawasi individu yang berada di dalam bagian lingkungannya. Oleh sebabitu, dampak yang diberikan kepada orang Madura (pendatang) sebagai hasil dari proses adaptasi adalah penerimaan dirinya di tengah masyarakat dan dipercaya sebagai orang yang ingin berubah dari masa lalu.

3. Memiliki keleluasaan untuk hidup bermasyarakat. Masa lalu yang suram dan kesalahan dalam melanggar norma di masyaraka tmenjadikan orang Madura (pendatang) yang saat itu hidup tercengkam 
dengan rasa takut dan was-was ketika melakukan sesuatu hal diluar rumah. Namun, saatini orang Madura (pendatang) mengalami perubahan dan melakukan adaptasi di tengah masyarakat. Hasil yang mereka dapatkan ditunjukkan dengan adanya bentuk keleluasaan dalam bergaul dengan masyarakat. Hal tersebut karena orang Madura (pendatang) sudah tidak merasa bersalah sehingga tidakada sekat yang membatasi orang Madura (pendatang) untuk hidup bebas dan leluasa namun tetap mengikuti aturan-aturan yang ada di masyarakat Desa Madu Sari.

\section{SIMPULAN}

Pola adaptasi yang dilakukan orang Madura (pendatang) dengan lingkungan masyarakat di Desa Madu Sari yaitu dengan cara menunjukkan sikap ramah, berperan aktif membantu tetangga, menjalin komunikasi yang baik dengan tetangga dan masyarakat sekitar, Berpartisipasi aktif dalam kegiatan yang ada di dalam masyarakat serta menanggapi stigma negatif dengan bersikap biasa saja. Hambatan yang dialami oleh orang Madura (pendatang) dalam beradaptasi dengan lingkungan masyarakat di Desa Madu Sari yaitu kurangnya kepercayaan diri orang Madura (pendatang) untuk beradaptasi dengan lingkungan sekitarnya. Namun keinginan yang besarorang Madura (pendatang) untuk diterima dengan baik dalam lingkungan masyarakat menjadi sebuah kekuatan bagi mereka untuk tetap beradaptasi dengan mejadikan semua kritikan dan tekanan dari masyarakat sekitar menjadi sebuah motivasi dan nasehat bagi dirinya sendiri. Perubahan positif yang dilakukan orang Madura (pendatang) setelah diterima di Desa Madu Sari yaitu bertambah ikatan kedekatan dengan tetangga dan masyarkat dengan bersikap lebih tebuka tehadap lingkungan sekitar, lebih peka dan aktif dalam kegiatan kemasyarakatan, serta menjalin pergaulan yang lebih baik dengan lingkungan masyarakat serta menjauhi hal-hal yang negatif dan kebiasaan dimasalalu seperti anarkis dan arogan, maumenang sendiri, berperilaku keras, ego yang tinggi, serta melakukan tindakan yang dapat merugikan diri sendiri maupun orang lain dapat di cegah/di hindari.

Dampak yang terjadi setelah orang Madura (pendatang) melakukan adaptasi di dalam lingkungan masyarakat yaitu perubahan respon dari masyarakat yang awalnya khawatir dan kurang percaya (ragu) kepadaorang Madura (pendatang), kini berubah menjadi percaya dan bias lebih terbuka terhadap mereka sehingga mereka bias diterima di tengah masyarakat. Hilangnya stigma negative dari tetangga dan penerimaan orang Madura di tengah masyarakat sertadi percaya sebagai orang yang ingin berubah dari masa lalu. Memiliki keleluasaan untuk hidup bermasyarakat dari masa lalu yang kurang baik dan kesalahan dalam melanggar normanorma yang ada di dalam masyarakat menjadikan orang Madura (pendatang) yang saat itu hidup tercengkam dengan rasa takut dan was-was ketika melakukan sesuatu hal di luar rumah mejadi bebas dan leluasa dalam bermasyarakat yang baik tanpa harus melupakan aturan-aturan yang ada di dalam Desa Madu Sari.

\section{DAFTAR RUJUKAN}

Aminuddin. 2000. Sosiologi Suatu Pengenal Awal. Jakarta: Raja GrafindoPersada.

Bachtiar, W. 2010. Sosiologi Klasik Dari Comte Hingga Parsons. Bandung: Remaja Rosda karya.

Basrowi, Muhammad \&Soeyono. 2004. Memahami Sosiologi. Surabaya: Lutfansah Mediatama

Bernard Raho SVD. 2007. Teori Sosiologi Modern. Jakarta: Prestasi Pustaka.

Giring. 2004. Madura Dimata Dayak dari Konflik Kerekonsiliasi.Yogyakarta: Galang Press.

Judiht N. Martin. 2013. Komunikasi AntarBudaya Prasangka dan Konflik. Jakarta: Alfabeta.

Karta Sapoetra, G. 2008. Sosiologi Umum. Jakarta: Bina Askara.

Kingsley, D. 2004. Psikologi Sosial. Bandung: Refika Adiama.

Notoatmodjo. 2003. Ilmu Sosial dan Perubahannya. Pontianak: STAIN Pontianak Press.

Parsons, Talcott. 2010. Sosiologi Perubahan Sosial 1902-1979, Jakarta: prenada.

Suparlan, Parsudi. 2003. Keanekaragaman Suku Bangsa dan Kebudayaan. Jakarta: BalaiPustaka. 
Volume 12 | Number 1| April |2021, Page 13-23/ E-ISSN: 2715-1247 dan P-ISSN: 2087-84xx

Suparlan, Parsudi. 2004. Hubungan antar Suku Bangsa Masyarakat dan Kebudayaan. Yogyakarta: Ypkik

Ranjabar, J. 2008. Perubahan Sosial Dalam Teori Makro Pendekatan Realita Sosial. Jakarta: Erlangga.

Ritzer, George. 2014. Teori Sosiologi Modern: Edisi Ketujuh. Jakarta: Kencana Prenada Media Group.

Robert, H, Lauwer. 1993. Sosiologi Untuk Universitas. Bandung: PT Refika Aditama.

Soekanto, Soerjono. 2009. Sosiologi Suatu Pengantar. Jakarta: Rajawali Press.

Sugiyono. 2006. Metode Penelitian Kualitatif. Bandung: Alfabeta.
Sugiyono. 2010. Memahami Penelitian Kualitatif. Bandung: Alfabeta.

Soekanto. 2009. Sosiologi Perubahan Sosial. Jakarta: Prenada Media Group.

Sotari, D \& Aan, K. 2009. Konsep dan Teori. Bandung Refika Aditama

Suyono.2004. Urbanisasi dan Adaptasi. Bandung. LP3ES.

Thomas K. Nakayama. 2007. Lintas Budaya Masyarakat Multikultural. Jakarta: Liliweri Alo.

Winardi, J. 2006. Manajemen Perubahan. Jakarta: Prenada Media Group.

Wulandari, Dewi. 2009. Sosiologi Konsep dan Teori. Bandung: Refika Aditama 